\title{
School, homomaternity and education: reflections about the classroom in contemporaneity*
}

\author{
Escuela, homomaternidad y educación: \\ reflexiones sobre las clases en la contemporaneidad
}

Recibido: 2 de febrero de 2015/Aceptado: 18 de septiembre de 2015

http://doi.org/10.17081/psico.19.35.1214

\author{
Yáskara Arrial Palma ${ }^{1}$ \\ Faculdade de Desenvolvimento do Rio Grande do Sul (FADERGS- Laureate International Universities) - Brasil \\ Marlene Neves Strey ${ }^{2}$ \\ Pontifícia Universidade Católica do Rio Grande do Sul (PUCRS) - Brasil
}

Key words:

Gender, Homomaternity,

School, Family diversity,

Social psychology.

\section{Palabras clave:}

Género, Homomaternidad,

Escuela, Diversidad familiar,

Psicología social.

\begin{abstract}
This paper aims to provide a discussion on the topic homomaternal family and school. To this end, a qualitative research study was performed through narrative interviews which were conducted with four pedagogical supervisors from four schools located in the south of Brazil. After signing the informed consent, the interviews were recorded and transcribed, subjected to discourse analysis from the perspective of feminist studies of gender and Socio-Historical Social Psychology. The results show that despite the political and social efforts, there is still much resistance in the reflection of the subject in schools, guided by a heteronormative and patriarchal society. Therefore, an effective work on the subject is urgent in schools, so that prejudice and discrimination may decrease in Brazilian society.
\end{abstract}

\begin{abstract}
Resumen
Este artículo tiene como objetivo proporcionar una discusión sobre la temática: familia homomaternal y escuela. Con esto, se llevó a cabo un estudio de investigación cualitativo, de entrevistas narrativas con cuatro profesoras de la orientación educacional de cuatro escuelas ubicadas en el sur de Brasil. Después de la firma del consentimiento informado, las entrevistas fueron grabadas y transcritas, sometidas al análisis del discurso desde la perspectiva de los estudios feministas de Género y Psicología Social Socio-Histórica. Los resultados muestran que a pesar de los esfuerzos políticos y sociales, hay todavía mucha resistencia en la reflexión del tema en las escuelas. Esto, guiado por una sociedad brasileña heteronormativa y patriarcal donde es urgente un trabajo efectivo de reflexión para los cambios sociales.
\end{abstract}




\section{Introduction}

Thinking education within the context of family diversity is a challenge that presents itself in a society that is in full expansion of concepts, precepts and customs. Social norms are being presented with their new clothes, even at slow speed, re-introducing themselves in different ways to keep up with trends in the current historical moment.

The relationship family-school lies transformed because today brings numerous ways of being family, and not a single grounded in heteronormativity father, mother and child. This model of the bourgeois nuclear family has its roots in the capitalist model and is based on the patriarchal system (Cunha \& Alves, 2014), where the construction of a model that would ensure the family's property was fundamental, and even be based on a person, the father, the "boss" of that family.

Among the numerous family models, there are families consisting of two mothers or two fathers, in which the heterosexuality is not present. The children arising from these homes are sitting in classrooms, in different national school contexts. Family dynamics transformed themselves and introduced the subject of family diversity into schools.

But the question is on the issue mentioned above, about how the issue of sexual orientation presents and visualizes the moment that families formed by gay and lesbian pass to score its existence, either in filling the registration from the school or in the speech of children with two mothers or two fathers. The interest is then in how schools are noticing these changes, and especially how they are been understood?
Are questions of great importance, because they bring to light an old theme, which is the issue of sexuality. One way or another, sexuality is traversed in schools and cannot simply be denied due to the idea that the school is not responsible for this aspect in the development of children and adolescents. If the school is not responsible, the family should take charge of this debate with their sons and daughters. Regarding the division of responsibility for education of children between family and school, there are many theoretical positions (Nogueira \& Tavares, 2013).

Within this debate about the division of responsibility in the education of children and adolescents, it can be seen that there have been many changes over time, because in the British, American and French schools in the 50's and 60's, the academic success of the child was directly associated with the economic issues of the family. Soon, more informed children, in all respects, would reiterate social differences and social stratification legitimized by school (Nogueira \& Nogueira, 2015).

Even if there is an understanding by the school that the sexuality issue is the responsibility of both institutions into a position of educational theories from the eighties, yet the difficulty of working with the theme appears quite clear in teaching institutions (Altmann, 2013a).

However, sexuality is still seen in the school contemporaneity as the order of the individual and not as of the social order. So the theme will only be crafted in the individuality of referrals to the Educational Guidance Service (EGS) or the Psychology school sector. The possibility of a more extensive work will be required only if the problem in question is perceived as unduly ex- 
panded the order of private (private conversation) to the public (in class activity) (Avila, Toneli \& Andalo, 2013).

In the Brazilian school reality, from the end of the nineties, the Brazilian government implements guidelines that should be taken as parameters in public schools. The National Curriculum Parameters (NCP) introduces the theme of "sexual orientation" to the school curriculum, to be worked transversally in the school subjects that the teacher judged that would fit the context. But even with the attempt in the documents of the expansion of the idea of sexual orientation aspects as gender and sexual diversity, the issue still falls under the old optical biologicist, both in reading as in the educational practices of teachers in classrooms (Pretto \& Lago, 2013).

Sexuality turns to be responsibility of the school and should also be discussed and reflected in the classroom, from the private to the public and introducing mechanisms of social control, in that it produces power and knowledge that overlap others and thus legitimate. Documents vaguely guide on how the theme should be worked, citing the physical education class would be a privileged space for such, understanding the sexuality as a topic related to the body (Altmann, 2013b).

When sexuality is discussed, it is implicit that heterosexuality is the case, the type of sexuality in the current social order. This question is naturalized and is repeated daily within the family and other social institutions that regulate the normative and also the school, which is an important regulatory mechanism of the State (Barreiro, 2013). However, there is no denying the presence of the various existing sexualities, because even being considered as "other", which suggests that there is a standard model, are empowered and claim their space in the social fabric.
Among those other sexualities, we have the crossing of gays and lesbians both in school and meetings of mothers and fathers as guardians of the children. But strangely this perception is invisible due to some directions and teachers/s, which have no internal or external resources to understand the contemporaneity has many ways of being and living, contemplating sexuality and also the family.

If there is a lack of preparation of the educational system to work with issues related to sexuality, even when it is synonymous with heterosexuality, when the issue of sexual diversity presents itself, this difficulty increases. Hence, the need for education for sexual diversity becomes essential and urgent, because social transformations present and with them, the need for educational institutions monitor these movements.

It would be a dense justification to think that the twenty-first century provides visualization of the phenomenon of gay or lesbian orientation, which three decades ago would be considered a disease and is currently only targeting the desire for the same sex. At this point, it combines the creation of several laws in Brazil and around the world about the rights of same-sex couples, both as in wedding laws as the creation of the institution Family (Maciel, 2014).

Through the media, the expansion of the concept of sexuality can expand, either in print or broadcast media, whether in novels, that popularly assist in the creation and construction of social norms. Lesbian characters in the novels of a major Brazilian TV channel: Globo Telecommunications are examples of contribution to the expansion of the idea of family relationships and also because through the media, society transforms 
the themes of lesbianism and homosexuality and place on the level of common sense (Borges \& Canuto, 2013).

If there is a social change in relation to sexual orientation and it is gaining share in Brazilian society, can be thought then that school institutions monitor this process, since even the government guidelines request that this theme is crafted in the classroom. However, the school reality is differentiated and many times does not follow the flow of social change.

The National Curriculum Parameters (NCP) addresses the concept of sexual orientation facing an organization of sexuality and minimally include in the concept, modes of experiencing it. However, public schools and private schools are also at the mercy of the way that people who are part of the coordination of teaching decide to interpret these parameters and also the personal positions of teachers who make up the team of professionals. And in many instances, neither direction nor faculty is prepared for such (Avila, Toneli \& Andalo, 2013).

The process of education is often based on theories and dynamics guided in dichotomies, and among them is the notion of body and mind. Soon, teachers and students focus in mind, forgetting the body, which is only remembered for being a place of engendering educational practices. Within this issue, the culture allows the mind to discipline the body, bending it to certain ways of being in the world (Wenetz, Stigger \& Meyer, 2013).

When thinking about ways of being in the world, you must understand that what is being treated is heteronormativity, because the school when dealing with sexuality is fixed on an understanding of sexuality as reproduction of a heterosexual couple. With this, reiterates the existence of a naturalization of sexuality, normalizing bodies, gender, affection and love (Andrade \& Meyer, 2014).

Thus, educational practices are based on binary logic, legitimizing identities ruled in heterosexuality. With this there is no room for other meanings that present themselves on the margins of society, and when there is, it's associated with stigmas and stereotypes, which reiterate the current regulations (Passamani \& Ferreira, 2013). This reality is blurred in the discourses of respect and solidarity that permeate the school benches, because in most cases prejudice is reiterated without at least it is perceived or questioned.

Working sexual diversity in schools alone would be the point of relevance to the extent that society has students and gay and lesbian students and mothers and fathers constituting same-sex households. But beyond the visualization of the phenomenon, the importance expands as it can contribute to combating violence that occurs within schools, promoting avoidance, school failure, guilt, marginalization, fear, exclusion, expulsion and even high suicide rates compared to heterosexual students (Graupe \& Grossi, 2013).

Given the undeniable importance of visualization and debate about sexual diversity within the school, this article will address, among these diversities, the lesbianism while affective and sexual orientation of mothers who constitute their homomaternal families, through the discourse of the school. These families are present in the daily life of many schools and family and school diversity relationship becomes very pertinent to the study of social psychology, to the extent that its reflection can 
serve as a means of resistance against social regulatory mechanisms theme.

\section{Method}

The study followed a qualitative descriptive design. A qualitative methodology was chosen because of the constructivist perspectives (social meanings and historically constructed, with the goal of developing an understanding that contributes to theory used) and also vindicatory/participatory perspectives (oriented policies for the phenomenon in question). This model provides that the phenomenon can be understood in its depth and in its relation to other social phenomena (Coutinho, 2014).

As associated with qualitative technique strategies, narrative interview to perform the collection of research data was used. The narrative interview is suggested to be used in qualitative research by providing an understanding in depth the phenomenon studied. The researcher asks the respondent can reflect and narrate about a stimulus (Weller \& Zardo, 2013).

This study was conducted with the educational guidelines of four schools which had sons and daughters of families who had been previously interviewed, consisting of two mothers, enrolled and attending the educational institution in question. Among the four participating schools, two schools are private, one for kindergarten and one high school and two are public schools, one elementary school and one high school. The schools are located in the capital and metropolitan region of Rio Grande do Sul, southern Brazil.

In relation to the presented stimulus, the pedagogical supervisors were asked to talk about the relation school $\mathrm{x}$ homomaternal families. As the schools were contacted after conducting a narrative interviews with the mothers of the children who were enrolled in each school, many supervisors have waited contact to participate in research.

The data collected through narrative interviews were recorded and transcribed, after reading and signing the consent form. The study was conducted in accordance with the ethical guidelines established for human research of the National Health Council. The project was submitted to the Scientific Committee of the Faculty of Psychology of the Catholic University of Rio Grande do Sul (PUCRS) and the Ethics Committee of the same institution before the beginning of data collection. The same was approved and has the CEP 11/05689 record. The names of participants and schools were preserved and used fictitious names to nominate the lines.

The transcribed narratives were analyzed using discourse analysis according to Ferreira e Traversini (2013). The discourse analysis used in this study with the pedagogical supervisors of the schools was associated with the perspective of feminist theories of gender studies (Prá, 2014). Gender studies when combined with feminist studies understand gender as the asymmetric relationship between the male and the female, being a crossed patriarchy and reiterating the concept of patterns and misogynists sexist behavior.

Although the concept gender carry with it the binary female/male, the crossing of feminist studies and also the Socio-Historical Social Psychology bring the concept to a position of overshoot of the binary. Deconstruct the genre is to use it as a theoretical framework so that associations socially related to female and male may be transformed, helping to minimize the stereotypes and prejudices that trap ways of being and living. 


\section{Results and discussion}

Despite being a reality that occurs in most schools, the presence of families formed by gay and/or lesbian still causes discomfort in the school body. This statement brings a close relationship between the formation and training of teachers, public/private dichotomy and whether or not there is the opening of the school to address issues such as sexuality, without medical-hygienist bias.

A school is an institution marked by social role assigned to serve as responsible for inclusion of children in society as a citizen who has rights and duties. But it can also be understood as one of those responsible for creating a disciplined society, where male and female students are subjectivated by normative beyond school walls and end up in social life, directed by the knowledge-power devices (Foucault, 2014).

These different logics related to the roles of the school are interrelated, cross and overlap in the social transformations that contemporaneity features such as the existence of family diversity in recent decades. This increases the educational challenges towards realizing all your "duties" without forgetting the joints of powerknowledge traversed in schools.

The work arising from homomaternal and homoparental homes in schools allows children concepts such as family, gender stereotypes and sexual orientation are visualized as the school environment require these reflections. The way this dialogue will occur will depend on the look that is professional in daily intercourse with children, the teacher, since often the school does not provide moments where these concepts can be worked and developed more broadly (Oliveira, Brancaleoni \& Souza, 2013).
Soon, the "how" and "if" the topic sexuality, specifically sexual diversity is addressed will be of utmost importance to the reiteration of the status quo or deconstruction of the hegemonic model of heteronormative standards. So not only suffice the visualization of the theme in the work of the classroom, but the overcoming of established, a dialogue which follows the transformations of contemporary and head towards the deconstruction of stereotypes and standards for maintenance of social control (César, Duarte \& Sierra, 2013).

The speech below, a pedagogical supervisor who will be referred as The Advisor, exemplifies the issue on the work of the teacher, where it is understood that the same has an understanding regarding sexual diversity to handle issues that may arise in class: " there is no work with the teachers, I believe they already have this ability. The moment that you work with education, you are already open to all differences ...”

This question turns out to be quite delicate towards the assumption that there is an intrinsic respect to the difference to each student in the classroom by the teacher. However, this teacher was subjectivized in the same society that has devices to maintain order in the natural/normal/biological through the concept of heterosexuality.

Soon, teachers share the understanding that working with sexuality in the classroom is more than I need, because it is a topic that is directly associated with the overall development of children and adolescents. But when the discourse of sexuality appears inside the classroom, the teacher will build on the cultural effect of heteronormativity that subjected him/her, allowing other possibilities of sexuality to be considered non-school belonging (Avila, Toneli \& Andalo, 2013). 
The creation of the National Curricular Parameters ends up being a tool that attempts to standardize the way Brazilian schools will address the formal content and also content involved in school issues, such as gender and sexual orientation. But sexual orientation addressed in PCNs is not related to other possibilities of sexuality, there is still a very big connection with sexuality and issues such as HIV/AIDS and teenage pregnancy, blurring the possibility of reflection on the theme of diversity and serving again as more a device for social control (Altmann, 2013a).

However, the PCNs suggest thematics to support teaching work related to gender and sexuality, even if it is a sexuality with few crossings of diversity, but by no means an inspection will occur by the Brazilian government to make sure that the guidelines are being followed, and especially how they are being developed within the classrooms. The choice whether or not to address the issue of sexual orientation is at the discretion of the school as an educational planning or even of the teachers in their classroom moments. And the way this issue will be addressed will be crossed from scientificisms that bind to biologicist issues (Louro, 2013).

Allied to understanding of medical-hygienist sexuality is heteronormativity because as other sexualities are not thought within the school, they get marginalized and made invisible. What can be understood as a social backlash, since in the contemporary classrooms there are other sexualities beyond heterosexual and the families of children and adolescents also can no longer be understood only from the bourgeois nuclear model.

Think of heterosexuality still being considered compulsory in Brazilian society means also reflect on gender and its stereotypes, because the couple man and woman has certain pre-designed patterns that accompany the reiteration of the standard family model. Speech of Advisor B, the existing concern with the issue of the presence of a role performance "male" can be observed: "we always talk with families so that they have a male representative or until one of the mothers do this role because it is important for the child, parenting is the one that will give the child what the mother does not give, mom spoils and the male presence will not do that ... right".

The previous talks brings quite marked the presence of what is socially understood as related to the father, the man, and what is related to the mother, the woman. The association between the male and the question of limits is so deep that promotes an invitation to the woman: be the man of the family so that the child has a healthy development, expected.

This belief, a healthy child development associated with the presence of father and mother is founded on the existence of heteronormativity and gender stereotypes. Apart from the understanding that there is a standard family model for social good, there is a hegemonic construction of male and female, with assignments of strength and objectivity for men and women for sweetness and fragility (Pires, 2013).

This binary in the normative institution in sexgender-sexuality causes an immobilization of possibilities of being in the world, to institute heteronormativity and treating what is different from this design as part of the "other" (Junqueira, 2014). At this time, other modes of combinations are defined as above like different, odd, abnormal, as the case in homosexual and lesbianism, for example. 
The understanding of abnormality will be referred directly to the prejudice experienced by both gay and lesbian students as children and adolescents resulting from same-sex families and homomaternal Even though this issue is not clearly expressed by educational supervisors of the schools surveyed, the indices of prejudice in schools by the faculty are still quite significant in Brazil.

Within the theme of prejudice that exists in school, it is important to emphasize that no matter private or public, the question will permeate the classrooms, because regardless of socioeconomic issues, the notion of social norms permeate all social spaces. The Advisor A provides a comparison between public and private schools and their ways of dealing with prejudice: "I see that in public schools, especially teenagers, they make it clear, because as it's really in the periphery, they all live in the community, know of any relationship and here they are everyone, kind of individualistic, everyone has their own lives and they don't share more time together than here at school”.

Soon, the talk of the Advisor A brings directly implicated the issue of visibility or not of homo-affective relationship as a trigger for prejudice appears. Appears in public schools by engaging children and teens also be out of the classroom, because living in the same community and experience the existence of families of two mothers or two fathers. Already in private school, this involvement is limited to the school environment, so not much visibility into the family composition of students.

Prejudice whether you are connected or not with the visibility of lesbianism and homosexuality is a very interesting point, because clearly shows how sexual diversity arises the margins of Brazilian society in the XXI century. Moreover, it reiterates the role of school as a regulator of the social status quo, because the role of silencing and omission committed by the same breeder as social devices traversed by maintaining the sexuality model white, Western, bourgeois, heterosexual (Santos \& Dinis, 2013).

The speech of the Advisor $\mathrm{C}$ reiterates the point of invisibility, commenting that when children reflect on the fact that one of his colleagues have two mothers, the school has not manifested itself, having an idea that if it stayed in evidence could be understood as prejudice: "At first the kids and G. stated that he had two mothers. But always let them express themselves taking care not for emphasis, but responding clearly and smoothly".

This motion brought by Supervisor C, not focus on the issue of the presence of two mothers, refers to the existing play space in micro grids enrollment, the school being a place/space that is in the movement of words versus evidence (Meinerz, 2013). In this tension between recognition and the silence, the school is perceived in a mechanism of back and forth between taking itself as an institution in the service of the development of citizenship or repeats itself an ideological state institution.

The discussion about the importance of working to sexual diversity in schools returns because regardless of approach you take to discuss the issue, it falls again in the need of jobs that promote reflection and opening of new possibilities of thought. It is quite delicate to understand that there is no need to work the theme sexuality among the faculty, because it will be the interface between the school and the family inside the classroom (Rodrigues \& Wechsler, 2014).

The narrative below shows the "strangeness" that 
family diversity still cause when it brought in a visualized way what he perceives from the students at his school: "I realize that the subject is treated well controversial, because in my opinion is not the standard of family considered 'normal' by society. This type of relationship is strange to the kids, I've seen kids make comments that dismiss that kind of affective relationship (two mothers and two fathers)" (Advisor D).

The posture of the schools will be of inclusion and respect for diversity, as is quite marked in the speech of the Advisors A and C: "This is what we as a school have to see, we have to be ready to 'be' there for him to deal with other 'beings', that is the most important and why we are doing" (Advisor A); "Our school is open to all students, regardless of color, race, religion, sexual orientation or any syndrome. We always try to meet families in a welcoming way" (Advisor C).

However, not just the management team has to have a speech focused on the respect if the actions that take place within the classrooms often do not meet this stance. The use of the term "inclusion" was embedded in the narratives of both management teams and teachers, and to work toward unanimity on the inclusion just hiding beliefs and paradigms that are rooted in these professionals. These beliefs and paradigms eventually surface in doubt, referring to the inclusion of how it actually works, to get their speeches and put them into practice (Seffner, 2014).

Thus, the narrative of pedagogical supervisors at first are geared to work in diversity, to the idea that no matter how the family structure is, but the love and harmony that exists in that family. But once the narrative deepens the associations with different prejudices and stigmatization to the model of the bourgeois nuclear family announces: "Child of five years said - 'It's not normal two women date', while the child at three years was seeing the last scene of the soap opera - 'Mommy doesn't do so on her friend" (Advisor D).

And then the professional can perceive themselves disagreement between the beginning of the narrative brings and what appears in the continuity of the issues and are impressed: "Because it seems to lie but with all this technology we have, with all that lot of information, we still have some ingrained prejudices right, taboos, some things like that ...” (Advisor B).

The Brazilian school setting presents itself then filled with dichotomous, contradictory and conservatives who masquerade as interlocking discourses about the different discourses and social inclusion. This finding highlights the urgency of actions for which effective work on diversity actually occurs in classrooms. The Brazilian government is aware of this need and presents attempts to contribute to building a more "just and solidarity" school, which is in the construction of national curriculum guidelines, the school is trying to visualize the topic with the distribution of educational materials.

But the normative discourses arising from science, which associate to a still prevailing patriarchy, represented by a heteronormativity that is repeated daily, are placed as barriers against these attempts at social transformation. And then we hear calls for help for overcoming these barriers: "I think it's fundamental to discuss this issue and promoting it in a natural and peaceful way" (Advisor C), "It is important to work on this new family model, noting with students the importance of respecting the sexual choice of each one, once it will become more common in schools" (Advisor D). 


\section{Conclusion}

The thematic approach of school and family when intertwined with the educational guidelines of the resulting narratives enables reflection on the space sexual diversity occupies, so the homomaternal families can continue occurring. The need for work aimed at breaking paradigms and stigmatization that the school institution still bears appeared as fundamental in the struggle for the transformation of the educational system.

For more open that the school may be, it's subject to sexual diversity, it is involved in a game of strength which helps in sustaining micro grids of power-knowledge, in the place of "margin" gives room for the existence of a legitimate place which directs the desire to be where everyone wants. This logic reinforces the existence of prejudice and discrimination and creates concepts such as inclusion, for example, to account for the pursuit of a social "supposed fairness".

These arrangements and rearrangements of social devices permeate the subject of sexual diversity that, when crossed by the school, becomes entangled in overlaps. These overlays now attempt to express their reiteration of the status quo, now present themselves as social disruption devices, the struggle for existence of other possible subjectivities/familiarities.

This study was conducted with four of the seven schools, member in the research, as not all pedagogical supervisors of the schools where the resulting homomaternal homes of children are enrolled consented to participate. Some private institutions did not participate because they did not want to compromise the name of the school and some public by declaring lack of time due to the existing demands.
These negative can be understood as associated elements, devices built facing the provision of historical forms of exclusion and domination. However, breaches that evade norms continue to occur, even though the subjectivity of teachers or occasional social activities. And these disruptions occur in all social institutions, allowing the reformulation of social net and marking spaces stocks.

These spaces after marked, are established, even having the need to be routinely reiterating their rights of existence. And so the social changes continue to occur in an eternal negotiation of power plays that move and intertwine in society horizontally. While walls rise, others are dropped, so that life is fluid and new meaning, and more and more children and adolescents from homomaternal families will be seated at desks, writing and rewriting their stories, whether the school is prepared or not.

\section{References}

Altmann, H. (2013a). Diversidade sexual e educação: desafios para a formação docente. Sexualidad, Salud y Sociedad, 1(13), 69-82.

Altmann, H. (2013b). Barbie e sua história: gênero, infância e consumo. Pro-posições, 24(1), 275-279.

Andrade, S. S. \& Meyer, D. E. (2014). Juventudes, moratória social e gênero: flutuações identitárias e(m) histórias narradas. Educar em Revista, edição especial, (1), 85-99.

Avila, A. H., Toneli, M. J. F. \& Andalo, C. S. A. (2013). Posturas docentes: algumas (im)possibilidades e instabilidades da educação sexual que não fala 
de sexo School, homomotherhood and education in contemporaneity como prazer e direito. Em: Lago, M. C. S., Toneli, M. J. F. \& Souza, M. Sexualidade, gênero, diversidades. São Paulo: Casa do Psicólogo.

Barreiro, A. (2013). Um corpo estranho: ensaios sobre sexualidade e teoria queer. Pro-posições, 24(1), 269. 274.

Borges, L. S. \& Canuto, A. A. A. (2013). Saindo do armário? Uma análise da produção discursiva sobre o grupo LGBT na mídia impressa em Goiás. Comunicação $\mathcal{E}$ Informação, 16(2), 123-135.

César, M. R. A., Duarte, A. \& Sierra, J. C. (2013). Governamentalização do Estado, movimentos LGBT e escola: capturas e resistências. Educação, 36(2), 192-200.

Coutinho, C. P. (2014). Metodologia de investigação em ciências sociais e humanas: teoria e prática. Almedina: Ediciones Almedina.

Cunha, T. R. A. \& Alves, A. E. S. (2014). Educação e violência nas relações de gênero: reflexões na família, no casamento e na mulher. Em Aberto, 27(92), 69-88.

Ferreira, M. S. \& Traversini, C. S. (2013). A análise Foucaultiana do discurso como ferramenta metodológica de pesquisa. Educação $\mathcal{B}$ Realidade, 38(1), 207-226.

Foucault, M. (2014). Vigiar e Punir. Trad. Raquel Ramalhete. Petrópolis: Vozes.
Graupe, M. E. \& Grossi, M. P. (2013). As ações do núcleo de identidades de gênero e subjetividades (NIGS) e a agenda política de combate à homofobia, lesbofobia e transfobia nas escolas. Emblemas, 10(2), 203-220.

Junqueira, R. D. (2014). A pedagogia do armário: heterossexismo e vigilância de gênero no cotidiano escolar brasileiro. Annual Review of Critical Psychology, (11), 189-204.

Louro, G. L. (2013). Destemidos, bravos, solitários: a masculinidade na versão western. Bagoas, (10), 171-182.

Maciel, W. C. (2014). Novos (re)arranjos familiares e estereótipos de gênero nas decisões judiciais: a dimensão do cuidado e o reconhecimento da cidadania na homoparentalidade. Trama, 5(5), 43 59.

Meinerz, N. E. (2013). Se essas paredes pudessem falar. Bagoas, (10), 55-72.

Nogueira, C. M. M. \& Nogueira, M. A. (2015). Os herdeiros: fundamentos para uma sociologia do ensino superior. Educ. Soc., Campinas, 36(130), 47-62.

Nogueira, M. O. \& Tavares, C. M. M. (2013). Relação família-escola: possibilidades e desafios para a construção de uma parceria. Revista Formação@ Docente, 5(1), 43-57.

Oliveira, R. R., Brancaleoni, A. P. L. \& Souza, T. N. (2013). Formação de professores para o trabalho com o tema sexualidade no cotidiano escolar. Góndola: Ensenãnza y Aprendizage de las Ciencias, 8(92), jul-dec, 34-49. 
Passamani, G. R. \& Ferreira, K. (2013). Gestos descuidados em corpos indevidos: quando corpo, sexualidade e homofobia se encontram na escola. Emblemas, 10(2), 203-220.

Pires, M. I. (2013). A educação sexual na primeira infância: elementos para uma abordagem pós-estruturalista. Periferia, 5(2), 64-75.

Prá, J. R. (2014). Mulheres, direitos políticos, gênero e feminismos. Cadernos Pagu, (43), 169-196.

Pretto, Z. \& Lago, M. C. S. (2013). Reflexões sobre infância e gênero a partir de publicações em revistas femininas brasileiras. Revista Ártemis, (1), 56-71.

Rodrigues, C. P. \& Wechsler, A. M. (2014). A sexualidade no ambiente escolar: a visão dos professores de educação infantil. Cadernos de Educação: Ensino e Sociedade, 1(1), 89-104.
Santos, W. B. \& Dinis, N. F. (2013). Adolescência heteronormativa masculina: a construção "obrigatória" e desconstrução necessária. OPSIS, Catalão, 13(2), 129-149.

Seffner, F. (2014). Sexualidade: isso é mesmo matéria escolar? Rev. Teoria e Prática da Educação, 17(2), 67-81.

Weller, W. \& Zardo, S. P. (2013). Entrevista narrativa com especialistas: aportes metodológicos e exemplificação. Educação e Contemporaneidade, 22(40), 131-143.

Wenetz, I., Stigger, M. P. \& Meyer, D. E. (2013). As (des) construções de gênero e sexualidade no recreio escolar. Revista Brasileira de Educação Física e Esporte, 27(1), 117-128. 